\title{
ANALYSIS OF PRODUCT AND CULTURAL DIVERSITY AS AN OPPORTUNITY TO INCREASE MARKET EXPANSION FROM SHOCKED MARKETS TO E.COMMERCE AT MASJID AL-FALAH SURABAYA
}

\author{
Noneng. R.Sukatmadiredja \\ rheina1060@gmail.com \\ Emmywati \\ emmywati1606@gmail.com \\ Iwang suwangsih \\ 1wangsuwangsih81@gmail.com \\ Nuzulul Fatimah \\ nuzulul1025@gmail.com
}

\begin{abstract}
"Analysis of product and cultural diversity as an opportunity to increase market expansion in shock markets towards E.Commerce at Masjid Al-Falah Surabaya", aims to analyze the opportunities created by the shock market to market opportunities with E.Commerse the market was shocked to become a digital market, namely $\mathrm{E}$.commerce. The study was conducted at Masjid Al = Falah Surabaya with an unknown population, with a random sample of 40 respondents. Analysis of data by analyzing, purchasing activities caused by product diversity and cultural factors, these two variables can influence purchasing decisions, purchasing decisions can be increased repurchase through e.Commerce. The results showed that respondents who decided to buy were divided into buying because there were 26 respondents equal to $65 \%$, respondents who did not buy 0 , while 14 respondents who had impulse buying were equal to $35 \%$. Whereas respondents bought goods because the quality of the product varied some 34 respondents, equivalent to $85 \%$, respondents who bought because it was by the type of product were 32 respondents equal to $80 \%$, while respondents bought because the price was cheaper were 37 respondents, equivalent to $92.5 \%$, buying because the culture was $100 \%$, whereas because of the sub-culture there are 8 respondents, namely $2 \%$, while the social class of almost all social classes buys means $100 \%$. The analysis of market increase can be seen from buyers who carry out repurchases, this can be seen from there are 11 respondents equivalent to $27.5 \%$ through electronic media, either WA, Instagram, or COD. It can be concluded that opportunities can be taken from the traditional market shock to the E.Commerce market.
\end{abstract}

Keywords: Product diversity, Culture, Purchasing decision, E.commerce.

\section{Introduction}

In an era that has entered the industrial phase 4.0 where trading systems and transactions are mostly carried out using e-business and e-commerce, traditional markets will continue to shift into modern markets. From these conditions, it turns out that in Indonesia as a developing country there are still unique types of traditional markets that still exist today, including the keeping market, or impromptu markets, the kliwon market, and there are still 
many markets that do not operate every day. In large mosques on certain days, religious activities become places of religious tourism, due to their culture, there is an exchange between buyers and sellers, at the Al Falah Mosque, Al Akbar Mosque, for example, every religious holiday or Friday a market called the shock market will be created. Many retailers sell a variety of goods to service products. while the traders in the market are surprised to be a potential entrepreneur, and if it is developed with digital application innovation it is very possible that these traders can become entrepreneurs with digital innovation, so that starting from the market is shocked to become an entrepreneur with e-commerce and for this researcher is an interesting thing to research. Sonata Christian in the journal entrepreneur and entrepreneurship vol 2 states that the spirit of entrepreneurship must be encouraged to increase the independence of the Indonesian economy.

Based on preliminary observations, it was found that there was a shock market around the Al Falah mosque in Surabaya, East Java, Indonesia. In this area every Friday many traders came when Muslims performed their prayers. Some goods and services are traded, ranging from necessities, souvenirs, accessories, and many other interesting items that are traded so that people who have finished their Friday prayer services can shop according to their needs at the same time. These traders began arriving before Friday prayers and closing their merchandise shortly after the Friday prayers were finished, therefore it is called a shock market because a momentary market that occurs when there is a crowd or celebration such as Friday prayers where Muslims gather, this incident is used by traders to sell. The enthusiasm and involvement of consumers greatly influence the existence of this shock market. Also, this happens because of a kind of tradition that is created, a lifestyle and psychologically provides information to consumers, so that many of those who come have prepared a certain amount of money to buy goods as needed. This shock market also in terms of the marketing mix provides information about product diversity, direct distribution channels, as a promotional event for the various products offered, according to taste, of course at relatively cheap prices, when compared to modern markets. So that this shocked market environment can trigger people who have finished worshiping to the crowd and gather to see and make decisions to buy. From the merchant's point of view, traders are certainly the forerunners of an entrepreneur. Where an entrepreneur will be able to overcome one of Indonesia's economic problems, especially Indonesia's macroeconomic problems. Based on this phenomenon, the authors raised it as research.

\section{Literature review and previous research and its relationship with research analysis}

Ima Rachina Nazir and Muflihul Iman in the journal SCALE ISSN: 2338-7912, Volume 5 of 2018 examines the phenomenon of shock markets as hybridity of traditional market systems in urban spaces, resulting in research that hybrid space in a special shock market formation is present as a formal-informal relationship which is interrelated. In connection with this research, of course, furthermore, if the market is shocked to create MSME business opportunities, which can participate in maximizing direct sales if this is developed towards ecommerce in various forms, it does not rule out that a surge in purchases will occur. This phenomenon creates opportunities to increase sales volume, as well as customer loyalty.

Istijabatul Aliyah, Bambang Setioko, Wisnu Pradoto, in the journal homepage: wwwelseiver.city, culture, and society, researched the traditional market of Pasar Gede in Surakarta, resulting in a traditional market, apart from buying out of necessity, is also a place of recreation where some people carry out meetings and become a very special culture for the community. In connection with the research that is being carried out, namely where the traditional markets that no longer need promotion will certainly have a positive impact on increasing sales and purchasing/transaction convenience if e-commerce innovation is applied. This is an opportunity if transformation is Digital applied to similar markets. 
$\mathrm{n}$ the context of the discussion of this research, several supporting theories are considered in this study, Sofjan Assauri (2013: 12), the notion of marketing management is the activity of analyzing, planning, implementing, and controlling various programs that are structured in the formation, development, and maintenance of profit from transactions. / exchange through the target market to achieve the company's goals in the long term. In line with this theory, then one of the reasons for research into the theory is reinforced because e-commerce certainly must be supported by sales promotion.

Definition of Shocked Market The market according to the meeting time of sellers and buyers is divided into five types, namely the surprising market, daily market, weekly market, monthly market, and annual market. According to KKBI, the Shock Market is a temporary market that occurs when there is a crowd or celebration. Examples of shock markets include when Muslims carry out Friday prayers. In connection with this research, the object of research is the shock market at Masjid Al-Falah Surabaya where the market occurs when Muslims carry out Friday worship and only for a moment.

Product Diversity Kotler (2000) in his book marketing management states that product diversity is a collection of all products and goods offered by certain sellers to buyers. Product diversity will create the availability of very varied quantities and types of goods, this results in many consumer choices during the shopping process. Meanwhile, Botti And Iyengar (2006) state that product diversity is an attraction for consumers because it can provide more varied alternative choices which encourage consumers to get satisfaction. Product diversity is a consumer's perception that is divided into several dimensions, including:

1. Perception of product diversity, this means consumer assessment of the various prices of the products offered.

2. The diversity of product quality is a consumer assessment of the various quality products offered.

3. The diversity of product types is a consumer assessment of the various types of products offered.

4. The diversity of product displays is a consumer assessment of the product display being offered.

In this study, the variety of products offered at Masjid al-Falah Surabaya, of course, varies from basic necessities, food, equipment, to Hajj and Umrah travel offers.

Culture Culture is an activity that is continuously carried out and has become a habit formed from many elements, including elements of religion, politics, customs, language, tools, clothing, buildings, and works of art. Culture is complex, abstract, and broad. Many aspects of culture determine consumer behavior. It can be said that culture can create a coherent framework for organizing one's activities and it can be possible to predict consumer behavior.

Cultural factors that can influence consumer behavior are culture, sub-culture, and consumer social class because the culture is a fundamental cause of consumer behavior desire to buy goods. Sub-culture can be divided into 4 types, nationalism groups, religions, races, and geographic areas. With culture will result in changes in consumer behavior, this will affect purchasing decisions so that it will also affect market segments. Culture in relation to this research is the habit of people who come to the Al-Falah Mosque, in addition to the surrounding residents there are also those who come from a radius of $5 \mathrm{Km}$ even up to 10 $\mathrm{Km}$, where in fact the mosque which holds the same activity is also close to the residence. So it becomes a dating culture to carry out worship as well as to make religious tourism, which can also buy necessities.

Purchasing Decisions According to Kotler (2009: 76), a purchase decision is an action by consumers whether to buy a product or not. Of the various factors that influence consumers 
to purchase a product or service, usually consumers always consider the quality, price, and products that are well known to the public.

According to Schiffman and Kanuk (2008: 6), purchasing decisions describe how individuals make decisions to utilize their available resources (time, money, effort) to buy goods related to consumption. In this study, it was examined, the percentage of visitors who buy, what underlies visitors to make these purchasing decisions. And why do they buy, are there any buyers who carry out repeat orders or repeat purchases made through online ordering?

E-Commerce in general can be defined as buying and selling transactions electronically through internet media. In addition, E-commerce can also be interpreted as a process of doing business using technology

In connection with the research that the researcher is carrying out there are several similarities and differences in objects or variables, including: research conducted by Tita Borshalina entitled "Marketing Strategy and The Development of Batik Trusmi in the Regency Cirebon which Used Natural Coloring Matters" yang diterbitkan oleh Science Direct pada tahun 2015, The research result showed the selling price becomes higher as it uses environmentally friendly of natural coloring materials managed or anticipated in inclining quality that it could be accepted by the consumers, the supporting factor of developing the market of Batik trusmi with natural coloring materials were many consumers interested in Batik Trusmi wich proved to be environmentally friendly and became the solution over the obstacle of increasing number of labors who were reluctant to work on batik colored with natural coloring materials that, in this case, SMEs of Batik Trusmi tried to provide inputs for the workers that Batik with natural coloring materials were quickly sold on the market.

The researcher at Istijabul Aliyah in the year of 2017 the title "Spatial Flexibility in Cultural Mapping of Traditional Market Area In Surakarta: A Case Study of Pasar Gede in Surakarta Published by Elsevier in the year of 2017, The research aims to reveal how spatial flexibility in cultural mapping in traditional market area particularly Pasar Gede of Surakarta by employing naturalistic paradigm, qualitative appoarch and several methods including 1) spatial analysis,2) Gategory based Analysis (AGB) and 3) Interactive Analysis. The result of this research refers to the theory suggested by Gallion, Pillai (2013), and Freitas (2016) that the activity variety will present spatial flexibility. On the other hand, the quesecenses occurred from spatial flexibility can be categorized as a form of space or building with the same function but it can still receive another activity without interfering with the main function. In this case, it contrasts with the theory explained by Rahadi (2008), and kroneburg (2007). Meanwhile, if it is examined based on temporary analysis by Carmona (2003), it can be categorized into Continuity and Stability an Implemented over time. In this case, the cultural mapping signifies that Pasar Gede area posseses flexible spatial function and can present sense of palace from symbiosis relationship between the physical,doers and livelihood. 


\section{Framework}

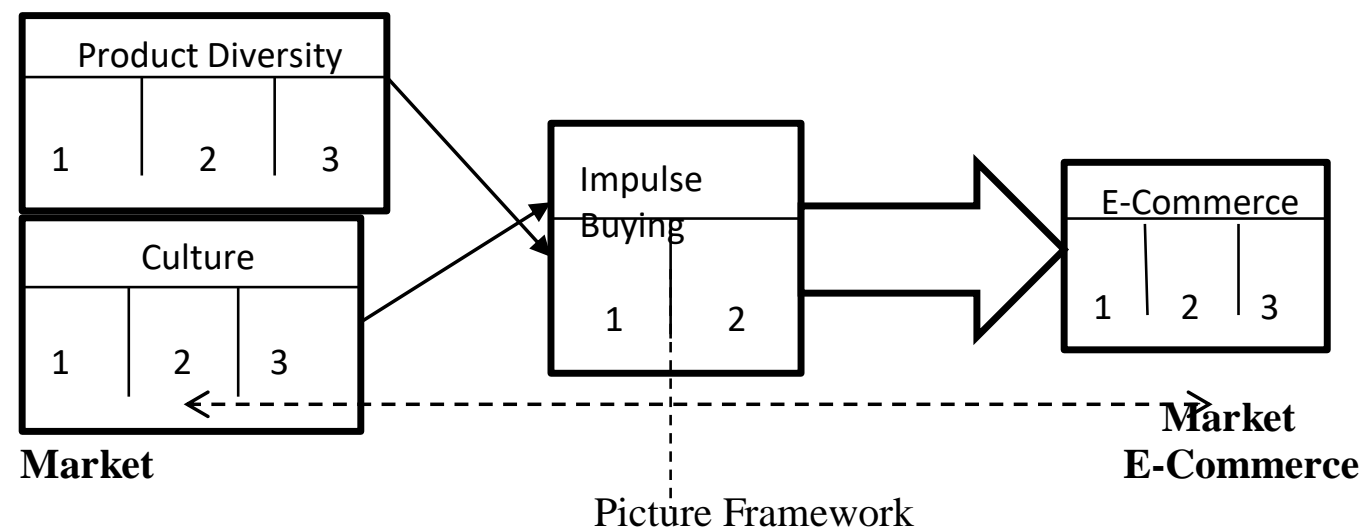

Source: Data processed researchers in 2019

information :

product diversity $1=$ quality of goods

product diversity $2=$ product type

product diversity $3=$ low prices

culture $1=$ culture

culture $2=$ sub culture

culture 3 = social class

purchase decision $1=$ planned

purchase decision $2=$ infulse buying

e-Cemmerce $1=$ Whats Ap (WA), Instagram (IG)

e-Commerce $2=\mathrm{COD}$ (Cash on Delivery)

e-Commerce 3 = Go Send

From the framework above, it can be seen some of the thoughts that underlie this research:

1. Purchasing decisions are based on product and cultural diversity.

2. The purchase decision occurred because of intentional or impulse buying.

3. Repurchasing is carried out with e-commerce, so there will be a transformation of transactions from traditional shock markets to e-commerce.

4. There is a big possibility of transaction transformation from the shock market to modern transactions by e-commerce.

\section{Research Methods}

This type of qualitative research is a type of research that produces findings that can be achieved (obtained) by using statistical procedures or other means of quantification (measurement). The quantitative approach focuses on symptoms that have certain characteristics in human life called variables, Sujarweni (2018: 14). By using the survey method, the generalizations made can be more accurate if a representative sample is used, David Kline in Sugiyono (2015: 14). Research conducted to collect information was carried out by compiling a list of questions asked of the respondents. In survey research it is used to examine the symptoms of a group or individual behavior. Data mining can be done through questionnaires and interviews, Sujarweni (2018: 89).

Population and Sample 
According to Sujarweni (2018: 105) Population is the entire amount consisting of objects or subjects that have certain characteristics and qualities that are determined by the researcher and conclusions are drawn. In this study, the population is all people who are carrying out Friday prayers together at the Al Falah Mosque, Surabaya, East Java, Indonesia whose number is unknown.

Rocque in Sugiyono (2015: 105) provides suggestions about the sample size for this study, namely the number of sample members is at least 10 times the number of variables studied. In this study the number of variables 4 x $10=40$ respondents (minimum number), we decided to take the number of 40 respondents that the researcher met 3 times every Friday in 1 month of the study.

Non-probability technique with purposive sampling, namely the technique of determining the sample with certain considerations or criteria. In this study, what is meant is the respondents who perform Friday prayers at the Al Falah mosque in Surabaya, East Java, Indonesia.

\subsection{Research result}

\section{Research Analysis and Discussion}

Respondents' data, the age of the respondents varies from 17 to 45 years, totaling 22 respondents or 55 percent, over 45 totaling 18 respondents equal to 45 percent, while respondents who deliberately came to the place were 32 respondents, the rest happened to pass by places of worship, respondents who came deliberately had distances houses are approximately between $1 \mathrm{~s} / \mathrm{d} 20 \mathrm{~km}$. while 8 respondents happened to have time to pray past the Al-Falah Mosque in Surabaya. The graph looks like this:

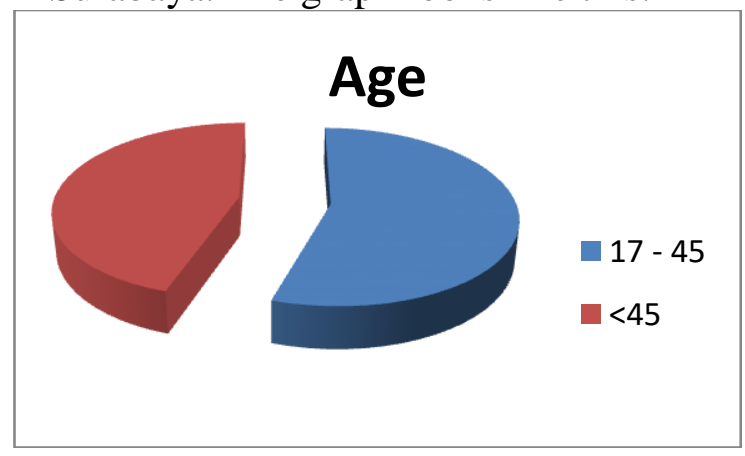

The purpose of the respondent's arrival.

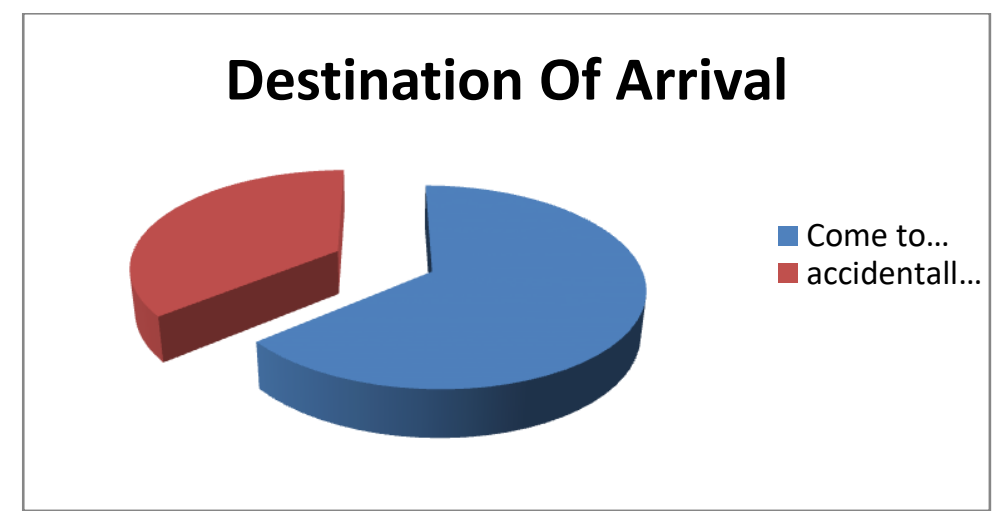

Of the respondents who deliberately came or happened to pass by deciding to buy were divided into buying because it had been planned that 26 respondents were equal to $65 \%$, respondents who did not buy 0 , while buyers who were impulse buying were 14 respondents equal to $35 \%$. 


\section{Impulse Buying}

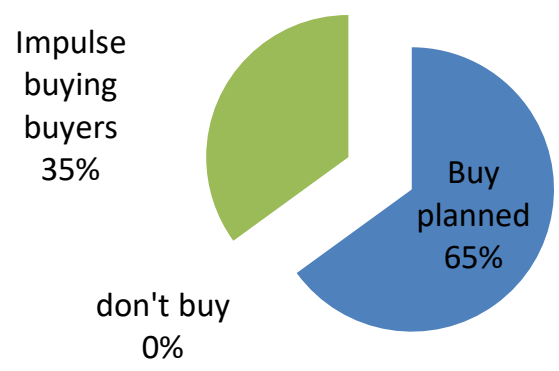

While respondents bought goods due to product diversity, 34 respondents were equal to $85 \%$, respondents who bought because they were following the needs of 32 respondents were equivalent to $80 \%$, while respondents bought because the price was cheaper were 37 respondents, equivalent to $92.5 \%$.

\section{Purchases due to product diversity}

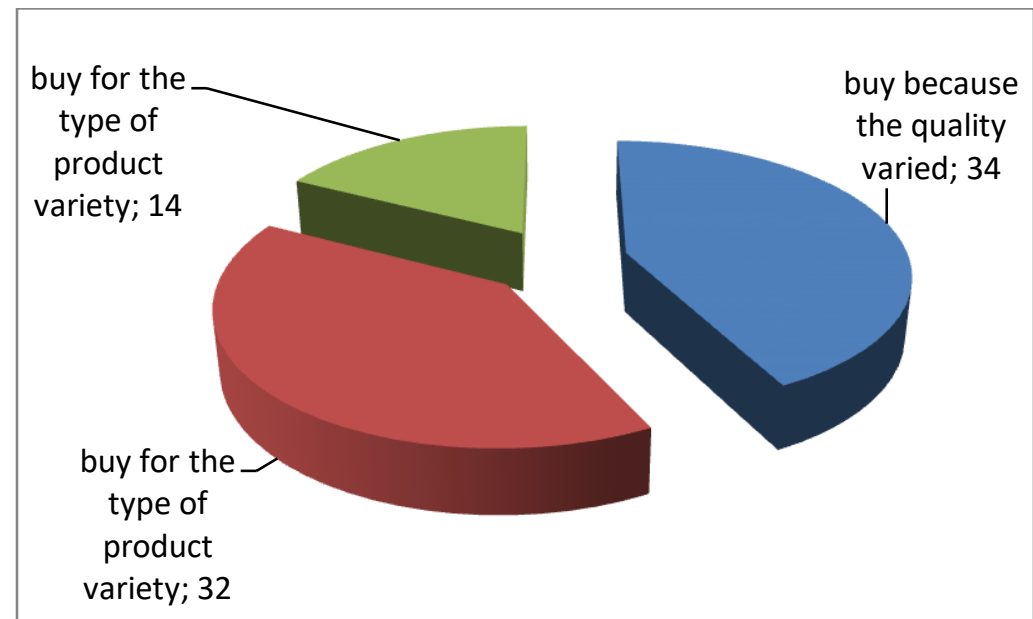

Purchase due to culture is $100 \%$, whereas because of sub-culture there are 8 respondents, namely $2 \%$, while social class almost all social classes buy means $100 \%$.

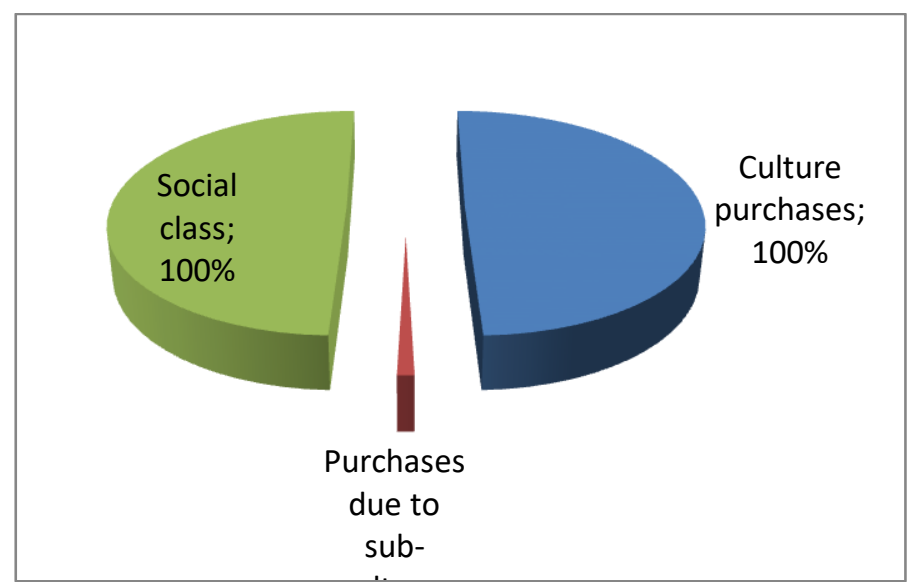


The analysis of market increase can be seen from buyers who make repeat purchases, this can be seen from there are 11 respondents equivalent to $27.5 \%$ through electronic media, either WA, Instagram, or COD. It can be concluded that opportunities can be taken from the traditional market shock to the E.Commerce market.

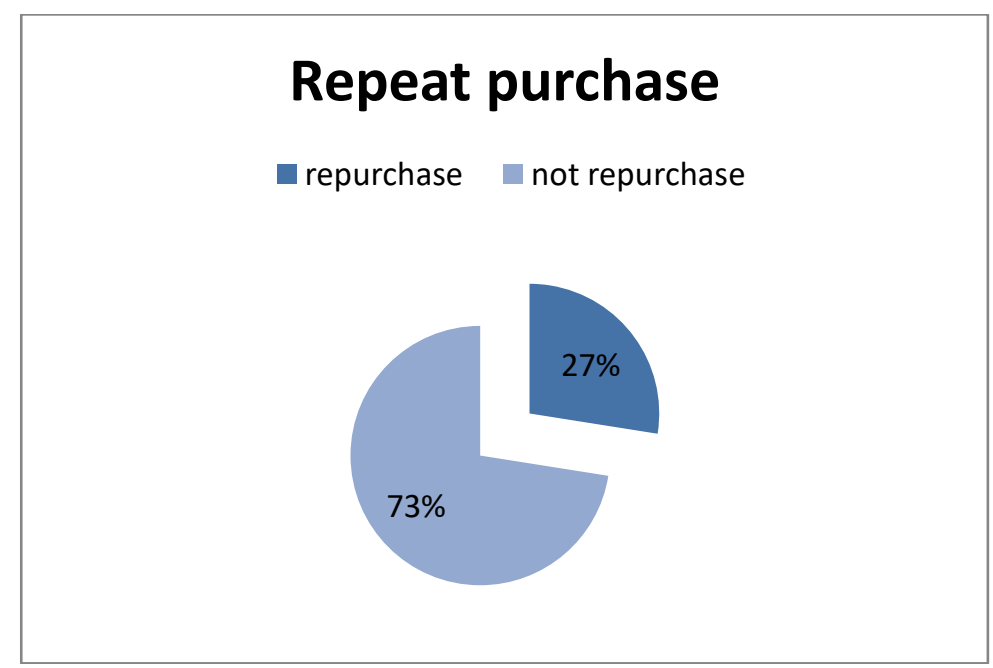

Digital tools used by consumers in repeat purchases, through WA, Go send, Messages. Seen as follows: Through the message 4 Consumers, prepared and taken when the consumer comes back. Via WA ordering goods and sent via Gosend or delivered yourself.

Seen in the following image:

\section{digital tool repurchase}

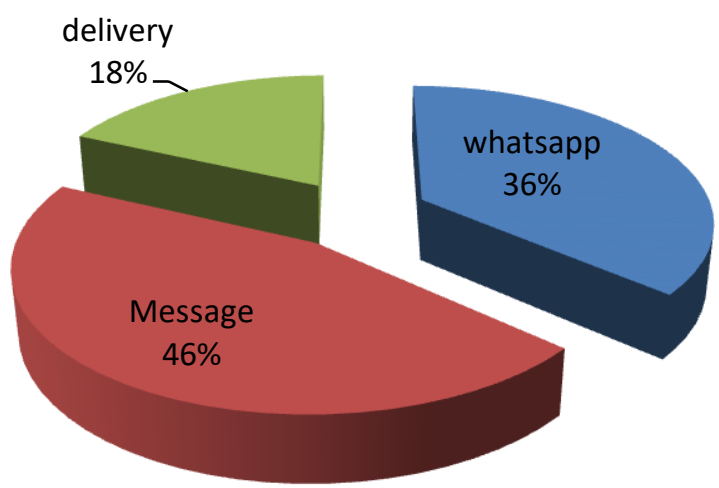




\subsection{Discussion.}

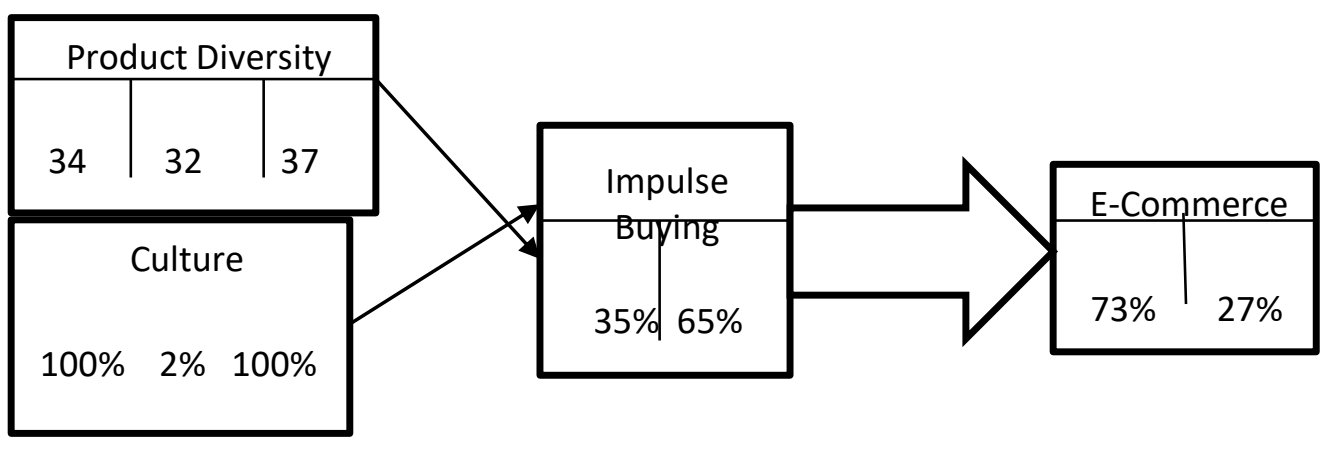

From several respondents, it will be obtained that respondents who decide to buy for various reasons, associated with increased purchases through e-commerce, are analyzed as follows:

1. Did the respondent buy on purpose or impulse buying?

From the sample studied, some results show that the purchase decision is dominated by deliberate intentions that have been planned. 26 Respondents are 65\%, this shows that $65 \%$ of market visitors are shocked that $65 \%$ already know the types of goods available in the market are shocked, the rest are 14 respondents equivalent to $35 \%$ are consumers who buy without planning, this kind of consumer certainly makes a potential customer and does not rule out being a loyal customer.

2. Is the purchase decision based on product diversity or because of culture?

From the research results, purchasing decisions due to product diversity can be seen from the items due to the various quality of 34 Respondents equal to $85 \%$, Consumers buy because of the various types of goods 32 Respondents are equivalent to $80 \%$, while consumers buy due to price variations are 37 Respondents equivalent to $92.5 \%$. This means that more than $80 \%$ of consumers buy because of good product diversity, because of the quality, types, and prices of various products.

Respondents who answered that buying decisions were due to culture, whether due to culture, sub-culture, or social class, almost $100 \%$, this means that consumers who come to Masjid Al-Falah have the same culture and have the same goals. Likewise, with social class hair, all respondents have an even social class and have togetherness in the sense that they do not differentiate between social classes because they are due to the same religion.

3. Will the respondent repurchase via e-commerce,

From the results of the research of respondents who carried out repurchasing of 11 respondents equivalent to $27 \%$, this means that if they are continuously given motivation and provisioning about digital science, consumers may gradually switch to digital through any tool, this means it can shift transaction behavior from traditional shock markets to ecommerce.

4. How big is the possibility of transforming traditional transactions into e-commerce?

Paying attention to the results of the above research, if retailers who are in the market are surprised to be given an understanding and a little capital for communication tools that can upload e-commerce applications, it is likely that the transformation of the transaction that begins with the shock market phenomenon becomes modern digital transaction and enters ecommerce. commerce. 


\section{Conclusion}

There are several possibilities for purchasing decisions made by respondents, namely decisions that have been planned or not planned. The purchase decision may occur due to the variety of products offered in the research object or due to culture. Of the respondents who made purchases either because of product diversity or because of culture, some respondents made repeat purchases, re-purchases occurred using digital means. Either through WA, messenger, or Go send. This means there is a transformation of transactions from traditional shock markets to modern transactions with digital or e-commerce. This transformation will likely occur.

\section{Newness}

This research allows the transformation of transactions in markets shocked by traditional sales, due to the diversity of products and cultures towards the e-commerce era, and contributes to lower-middle-class merchants to apply IT developments.

\section{Daftar Pustaka}

Assauri, Sofjan. 2013. Manajemen Pemasaran. Jakarta : Rajawali Pers.

Aliyah Istajabul,2017, Spatial Flexibility in Cultural Mapping of Traditional Market Area in Surakarta : A Case Study of Pasar Gede In Surakarta,journal Elsevier 10 (2017)4151.

Borshalina,Tita. Marketing Strategy and The Development of Batik Trusmi in the Regency of Cirebon which Used Natural Coloring Matters,Journal ScienceDirect 169(2015) 217 $-226$

Engel, J.F. et.al., 1994, Consumer Behavior, Jilid 1, Alih Bahasa Budiyanto,. Penerbit : Binarupa Aksara, Jakarta.Penerbit : Erlangga.

Firman, Maulana dan Saino, Analysis of factors that influence decisions Purchases at the traditional waru market in Sidoarjo, State University Surabaya

Femi Oktavian dan Diki Rustandi, implementasi digital marketing dalam Barand awareness, Profesi Humas, vol 3, no 1 tahun 2018.

Ima Rachima Nazir,Muflihul Iman, Fenomena pasar kaget:Hibriditas system Pasar tradisional di ruang kota, Jurnal ACALE ISSN 2338- 7912 ,Vol 5 No. 2 tahun 2018.

Muhammad Faris Fakhrudin, Nilawati Fiernaningsih, Pengaruh lokasi dan Keragaman produk terhadap kepuasan konsumen di Amstirdam coffee Dan roaster kota Malang, jurnal JAB Jurnal Aplikasi Bisnis vol 5. No 1 Tahun 2019.

Kotler dan Keller. 2009 .Marketing management. Jilid I. Edisi ke 13 Jakarta: Erlangga

Schiffman dan Kanuk. 2008. Consumen behaviour. Edisi 7. Jakarta: PT. Indeks.

Sugiyono. 2015. Statistik Nonparametris untuk for research. Bandung : Alfabeta. 
Journal of Islamic Economics Perspectives, Volume 3. Issue 2 (2021)

Sujarweni, V. Wiratna. 2018. Metodologi Penelitian Bisnis dan Ekonomi : Pendekatan Kuantitatif. Yogjakarta : Pustaka Baru

https://kbbi.kemdikbud.go.id/

https://gloriacharlotte.wordpress.com/2015/01/08/pengaruh-kebudayaan-terhadap-pembeliankonsumen/

$\underline{\text { Sonata Christian, Penggalakkan entrepreneurship sebagai langkah awal untuk peningkatan }}$ kemandirian perekonomian Indonesia, jurnal entrepreneur dan entrepreneurship, ISSN: 2302-1802. 